\title{
APPLICATION OF "PROGRAM OF CLINICAL-PSYCHOLOGICAL REHABILITATION BY OPTIMIZATION OF THE INTERNAL PICTURE OF HEALTH” IN PATIENTS AFTER ACUTE CORONARY SYNDROME
}

\author{
R.V. Nesterak
}

\author{
Ivano-Frankivsk National Medical University, Department of Internal Medicine №2 and Nursing, \\ Ivano-Frankivsk, Ukraine, \\ ORCID ID: 0000-0002-4062-0939, \\ e-mail: roxolana.nesterak@gmail.com
}

\begin{abstract}
Abstact. Aim. To analyze the effectiveness of the "Program of clinical-psychological rehabilitation by optimization of the internal picture of health" of patients after acute coronary syndrome at the stage of rehabilitation.

Materials. There were examined 120 patients with ST-segment elevation myocardial infarction, who were divided into groups with conservative treatment and thrombolytic therapy followed by coronary artery stenting. Clinicalanamnestic characteristics of patients, laboratory and instrumental data were analyzed, questionnaire survey according to the "Scale of Assessment of the Level of Reactive (Situational) and Personal Anxiety" of Spielberg-Khanin; quality of life according to the Seattle Questionnaire were performed. Traditional rehabilitation measures and rehabilitation with optimization of the internal picture of health were applied according to the "Program of clinical-psychological rehabilitation of cardiac patients by optimization of the internal picture of health".

Results of the study. In the group of patients who were performed thrombolytic therapy, a higher percentage of men aged 45-59 years were found, and in the group of conservative treatment the age of patients was 60-74 years and more than 75 years. Indices of reactive and personality anxiety levels were high at the beginning of the observation, regardless of the used therapeutic method. A month later, the reduction of the reactive anxiety levels was found, however, these changes were more significant in the traditional treatment group with the optimization of internal picture of health $(p<0.05)$. Positive dynamics of the lipid profile was revealed, with a decrease of atherogenic lipoprotein fractions. At the beginning of treatment, the lipid profile indices in both groups did not differ significantly. However, in the course of treatment, they decreased; these changes were observed more pronounced in the group of patients with traditional rehabilitation with optimization of internal picture of health. Quality of life index was low at the beginning of treatment according to all scales of SAQ questionnaire. However, after 6 months of treatment, higher quality of life was reported according to most scales in patients who were performed thrombolytic therapy with coronary arteries' stenting and the combination of traditional treatment with optimization of the internal health picture. The index of attitude to the disease according to the quality of life scale was low in all groups of patients at the beginning of treatment, but after 6 months of treatment with the use of traditional treatment with optimization of IPH a significant increase of this index was determined, at the beginning of treatment it was $-47 \pm 5 \%$, and after 6 months $87 \pm 4 \%(\mathrm{p}<0.05)$.

Conclusions. Application of the "Program of clinical-psychological rehabilitation by optimization of the internal picture of health" in patients after acute coronary syndrome improves the state of functional recovery of patients, making the clinical course of the rehabilitation period, indices of physical and psychological state better, contributes to the reduction of levels of personal and reactive anxiety and to the correction of dyslipidemia manifestations with the decrease of levels of atherogenic lipoproteins. Traditional rehabilitation with internal picture of health optimization creates the conditions for motivation to change behavioral risk factors, which encourages fuller use of secondary prevention tools.
\end{abstract}

Keywords: acute coronary syndrome, thrombolytic therapy, rehabilitation, program, internal picture of health.

Introduction. Ukraine is well ahead of the European countries in the prevalence of the ischemic heart disease, namely coronary heart disease is the leading cause of mortality among circulatory system diseases [1].

Acute coronary syndrome (ACS) is a clinical syndrome that is defined during a period of exacerbation of coronary heart disease and develops because of progressive restriction or cessation of myocardial blood supply through the coronary artery.

Now, it is generally accepted to perform conservative and/or reperfusion tactics for the treatment of ACS, i.e., thrombolytic therapy or surgical intervention. Criteria for the determination of the treatment tactics are stratification of the degree of risk of complications and the course [2].

In patients with ST-segment elevation myocardial infarction (STEMI), treatment tactics are directed to timely reperfusion; in this case primary coronary intervention on the basis of the results of treatment efficacy (number of recurrent heart attacks, strokes, mortality) usually exceed thrombolytic therapy results [3,4].

European and American recommendations regarding the use of revascularization methods are regularly reviewed and supplemented in accordance with current perceptions of the disease and treatment outcomes [5]. At the same time, the multidisciplinary approach in the 
treatment and rehabilitation of patients remains relevant.

In order to improve the effectiveness of treatment and rehabilitation of patients with coronary heart disease, the correction of the internal health picture is of great importance. The concept of "internal picture of health" (IPH) was offered by V.M. Smirnov and T.N. Reznikova as a special attitude of the person to his/her own health, which is expressed in the awareness of its value and efforts to improve it [6]. O.S. Lisova believes that IPH - is a subjective reflection of a state of health by the person, which determines the psychosomatic potential of the individual through the sensitive, emotional, cognitive, value-motivational and behavioral components [7].

Accepting the disease, the patient builds an idea of the disease and its limitations by integrating the internal picture of the disease into a new internal picture of health. It is important to understand that illness is only the part of the internal health picture, which will help to improve the behavior of self-preservation and selfrestoration. The formation of IPH is associated with the projection of the objective reality of health on human consciousness, with the subjective perception and experience of his/her health/illness [8].

Reduction of the negative impact of disease on the human life is possible through the correction of intellectual perceptions of current health condition and future prospects of the recovery, a set of measures to control emotions and experiences about the symptoms of the disease, as well as to build a system of behavior preservation and restoration of health [9].

Education in schools for patients who experienced MI, increases the level of knowledge about the disease, secondary prevention and rehabilitation, as well as facilitates their practical application through the correction of risk factors, improvement of life quality, ensuring a favorable course of the post-infarction period. Awareness of patients about their disease, patients' knowledge of basics of self-control and management of risk factors reduces the number of complications development [10].

Study rationale. Restoration of the functional state of the cardiovascular system after ACS is an important link of the multidisciplinary approach, along with medical treatment, invasive tactics, and psychological support.

Rehabilitation of patients requires a comprehensive clinical-pathogenetic approach, taking into account the condition of the coronary bed, the degree of damage to the heart muscle, impairment of the cardiac and peripheral hemodynamics, physical and psychological state. In this complex, psychological rehabilitation plays an important role.

The tactics of invasive and cardiac surgical interventions, as well as standards for the performance of the physical and psychological rehabilitation are being actively developed nowadays. Therefore, the performance of the scientific research that would comprehensively evaluate the package of restorative treatment of patients is important both from a scientific and practical point of view.

The objective of the study. To analyze the effectiveness of the "Program of clinical-psychological rehabilitation program by optimization of the internal picture of health" of patients after acute coronary syndrome at the stage of rehabilitation.

Materials and methods. There were examined 120 patients with ST-segment elevation myocardial infarction (STEMI), depending on the used treatment tactics; they were divided into groups with conservative treatment and thrombolytic therapy followed by coronary artery stenting. Diagnosis and treatment of patients was performed in accordance with existing standards of management of people with ischemic heart disease, which are based on the clinical protocol of medical care for patients with ischemic heart disease, approved by the order of the Ministry of Health of Ukraine.

Patients with STEMI were distributed according to nosological forms of the disease, methods of revascularization and applied methods of rehabilitation and restorative treatment.

Traditional rehabilitation measures included: a medical component with non-medical and medical effects and a physical component that was used depending on the functionality of the patient's respiratory and therapeutic gymnastics, dosed walking according to the appropriate programs.

Traditional treatment with optimization of IPH was in the application of the "Program of clinicalpsychological rehabilitation of cardiac patients by optimization of the internal picture of health", which is based on the author's certificate for scientific work № 75681 dated 29.12.2017 [11].

All patients of the rehabilitation department were advised to participate in the program of psychological rehabilitation. Classes were performed by the cardiologist and psychologist; they included an introductory conversation, 5 interactive lessons using training elements (60 minutes in duration), individual psychological counseling (60 minutes) at the request of individual subjects, post-diagnostic stage of program impact results. The main work with the participants of each program was in the form of counseling. The classes are built taking into account the components of the internal picture of health (IPH), each component was considered during a separate lesson. Classes were cyclic, groups were open, and each patient could join the group in the course of its activity without losing the logic of training. During the lessons, each patient was individually identified with a component that was meaningful to the individual patient and needed correction. Individual work was performed as it was necessary and at the request of the patient. During the participation of the program, patients diarized changes after each lesson.

Clinical-anamnestic characteristics of patients, laboratory and instrumental data were analyzed. Along with the clinical methods, there was a questionnaire survey "Scale for assessment of the level of reactive (situational) and personal anxiety".

Quality of life was studied according to the "Seattle Questionnaire of Life Quality for the Patients with Angina Pectoris" (Seattle Angina Questionnaire -SAQ) and its Scales of "Exercise Limitations - PL", "Angina Stability - AS", "Frequency of Attacks - AF", "Satisfaction with the Treatment - TS", "Attitude to the disease DP". Depending on the variant, the answers to the questions were determined from 1 to 5 points, followed by 
recalculation.

Patients were examined at the beginning of treatment, after 1 month and 6 months of restorative treatment.

Statistical processing was performed using "Microsoft Excel" and "Statistica" v. 10.0 StatSoft, USA. The results were subjected to statistical processing by the methods of variational statistics (arithmetic mean, standard error, standard deviation, confidence interval). The likelihood of differences between the comparison groups was determined using Student's parametric criterion. Statistical testing of hypotheses to determine the differences between nonparametric signs was performed using the $\chi^{2}$-criterion and the $z$-criterion. Results with $p<0.05$ were considered statistically significant.

Results of the study. The mean age of patients in the conservative treatment group was $71.06 \pm 1.52$ years, in the group of patients treated with thrombolytic therapy was $58.31 \pm 1.73$ years. The distribution according to the age and gender is represented in Fig. 1 and 2.

It was determined, that in the group of patients who were performed thrombolytic therapy a higher percentage were men aged 45-59 years, but in the group of conservative treatment, there were both men and women aged 6074 years and more than 75 years.

Clinical-anamnestic characteristics of patients are represented in Table 1.

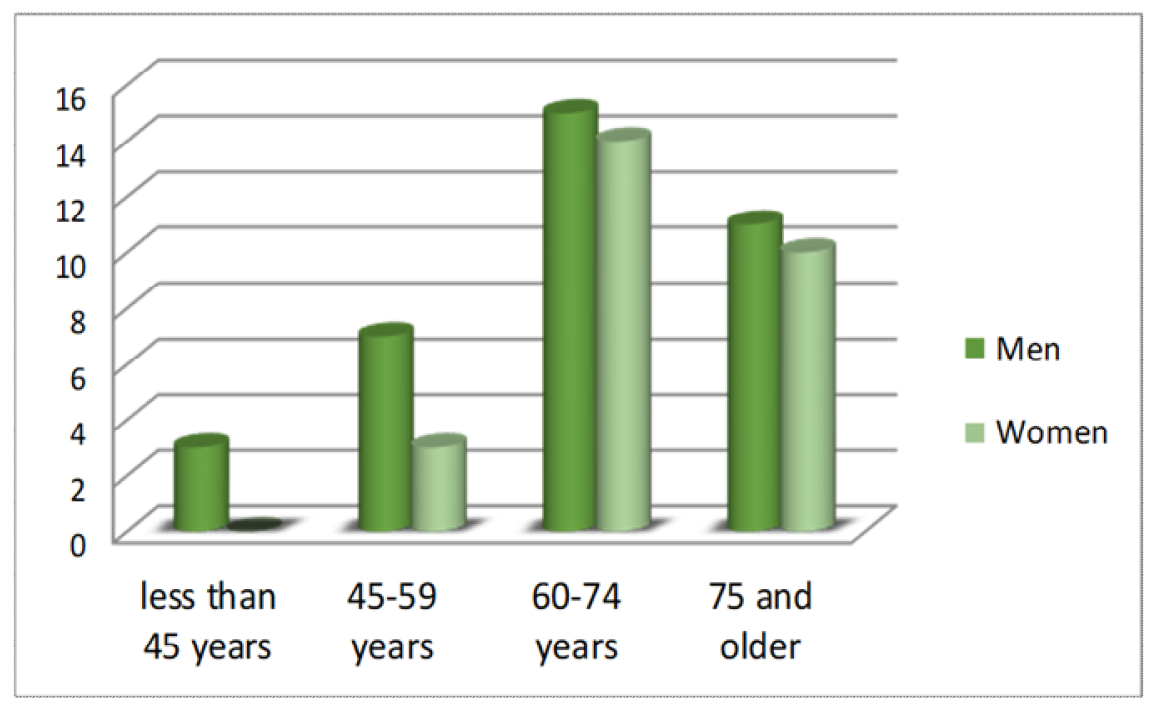

Fig. 1. Distribution of patients according to age and gender in the group of conservative treatment

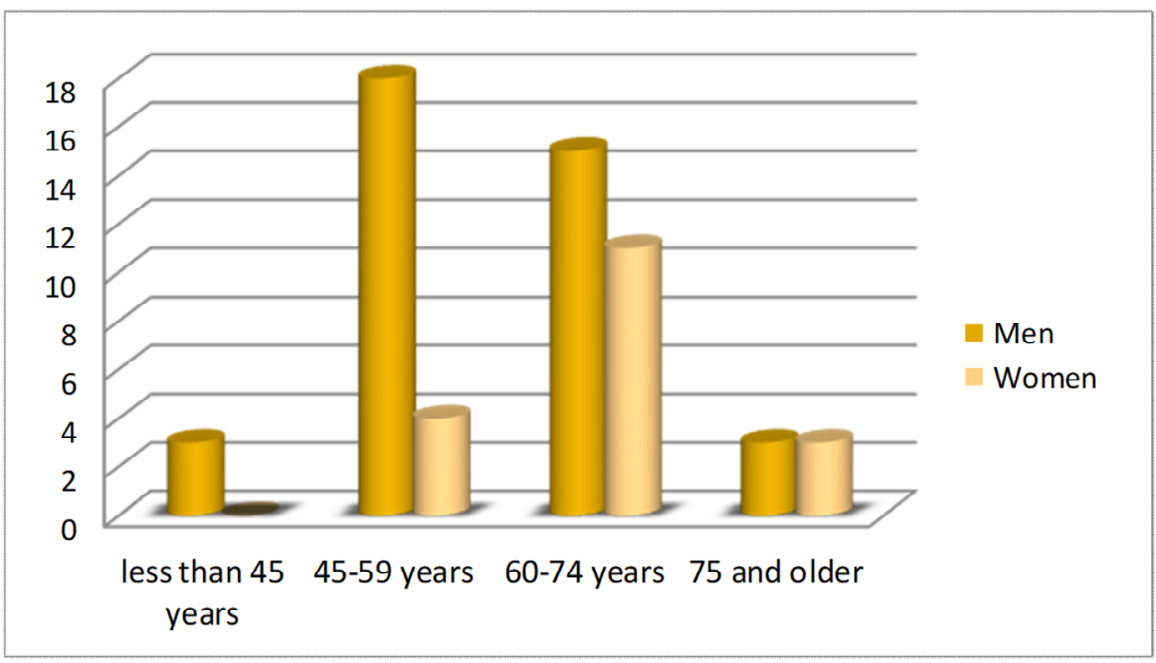

Fig. 2. Distribution of patients according to age and gender in the group of thrombolytic therapy 
Table 1

\begin{tabular}{|c|c|c|}
\hline \multirow{2}{*}{ Index } & \multicolumn{2}{|c|}{ STEMI $(\mathrm{n}=120)$} \\
\cline { 2 - 3 } & Conservative $(\mathrm{n}=63)$ & TLT $(\mathrm{n}=57)$ \\
\hline Residents of the city & $35(55.6 \%)$ & $20(35.1 \%)$ \\
\hline $\begin{array}{c}\text { Residents of the } \\
\text { village }\end{array}$ & $28(44.4 \%)$ & $37(66.7 \%)$ \\
\hline Without AH & $6(9.5 \%)$ & $6(10.5 \%)$ \\
\hline AH I degree & - & $5(8.8 \%)$ \\
\hline AH II degree & $43(68.2 \%)$ & $39(68.4 \%)$ \\
\hline AH III degree & $14(22.2 \%)$ & $10(12.3 \%)$ \\
\hline DM type II & $11(17.5 \%)$ & $5(8.8 \%)$ \\
\hline Without CHF & $4(6.4 \%)$ & $8(14.0 \%)$ \\
\hline CHF I & $9(14.3 \%)$ & $17(29.8 \%)$ \\
\hline CHF IIA & $18(28.6 \%)$ & $17 \%)$ \\
\hline
\end{tabular}

Notes: 1 . the absolute number of patients is indicated.

2. The percentage to the absolute number of the studied is given in parentheses.

Analyzing the indices of levels of reactive and personal anxiety according to the Spielberg-Khanin questionnaire in patients with ACS with ST segment elevation, there were revealed their high levels at the beginning of observation, regardless of the used treatment method. A month later, there was the decrease of reactive anxiety levels, more significant these changes were in the traditional treatment group with optimization of IPH $(p<0.05)$. In particular, in the group of patients with the use of traditional rehabilitation and conservative treatment at the beginning of treatment the level of reactive anxiety was (47.9 \pm 1.19$)$ points, in the group of optimization of IPH $(46.9 \pm 1.21)$ points, after 6 months, respectively $-(44.8 \pm 1.16),(36.0 \pm 1.15)$ points $(\mathrm{p}<0.01)$ (Table 2).

The dynamics of personal anxiety levels $(p>0.05)$ was less significant, but after 6 months, personal anxiety decreased in the group of optimization of IPH with the use of conservative treatment and it was $(40.6 \pm 1.18)$, and in the group of thrombolytic therapy $(38.2 \pm 1.19)$ points $(\mathrm{p}<0.05)$ (Table 3).

Indices of the Spielberg-Khanin questionnaire in patients with STEMI who were performed conservative treatment

\begin{tabular}{|c|c|c|c|c|c|c|}
\hline \multirow[t]{2}{*}{ Index } & \multicolumn{3}{|c|}{ Traditional treatment $(n=21)$} & \multicolumn{3}{|c|}{$\begin{array}{l}\text { Traditional treatment with optimization of IPH } \\
\qquad(\mathrm{n}=21)\end{array}$} \\
\hline & $\begin{array}{l}\text { At the be- } \\
\text { ginning of } \\
\text { treatment }\end{array}$ & 1 month & 6 months & $\begin{array}{c}\text { At the beginning } \\
\text { of treatment }\end{array}$ & 1 month & 6 months \\
\hline RA & $47.9 \pm 1.19$ & $\begin{array}{c}45.1 \pm 1.1 \\
8\end{array}$ & $44.8 \pm 1.16$ & $46.9 \pm 1.21$ & $40.5 \pm 1.18$ & $36.0 \pm 1.15^{* *}$ \\
\hline$\overline{\mathrm{PA}}$ & $47.6 \pm 1.21$ & $\begin{array}{l}45.8 \pm 1.1 \\
9\end{array}$ & $45.5 \pm 1.17$ & $47.8 \pm 1.22$ & $42.5 \pm 1.19$ & $40.6 \pm 1.18 *$ \\
\hline
\end{tabular}

Notes: Significance of difference of indices in comparison with values before intervention: $*<0.05 ; * *<0.01$.

Table 3

Indices of the Spielberg-Khanin questionnaire in patients with STEMI who were performed thrombolytic therapy and stenting

\begin{tabular}{|c|c|c|c|c|c|c|}
\hline \multirow[t]{2}{*}{ Index } & \multicolumn{3}{|c|}{ Traditional treatment $(n=19)$} & \multicolumn{3}{|c|}{$\begin{array}{l}\text { Traditional treatment with optimization of IPH } \\
\qquad(\mathrm{n}=19)\end{array}$} \\
\hline & $\begin{array}{l}\text { At the be- } \\
\text { ginning of } \\
\text { treatment }\end{array}$ & 1 month & 6 months & $\begin{array}{l}\text { At the begin- } \\
\text { ning of treat- } \\
\text { ment }\end{array}$ & 1 month & 6 months \\
\hline RA & $46.6 \pm 1.18$ & $41.5 \pm 1.16$ & $40.2 \pm 1.15$ & $47.1 \pm 1.19$ & $38.5 \pm 1.15$ & $35.0 \pm 1.16^{* *}$ \\
\hline PA & $48.3 \pm 1.20$ & $46.9 \pm 1.18$ & $46.3 \pm 1.17$ & $48.6 \pm 1.20$ & $41.5 \pm 1.17$ & $38.2 \pm 1.19^{*}$ \\
\hline
\end{tabular}

Notes: Significance of difference of indices in comparison with values before intervention: $*<0.05$; $* *<0.01$. 
At the beginning of treatment, the lipid profile indices in both groups did not differ significantly. However, in the course of treatment, they decreased; these changes were observed more pronounced in the group of patients with traditional rehabilitation with optimization of IPH. In patients with STEMI who were performed conservative treatment, the total level of cholesterol at the beginning of treatment was $6.19 \pm 0.13 \mathrm{mmol} / \mathrm{l}$, after 1 month $-4.65 \pm 0.22 \mathrm{mmol} / 1$ and $4.64 \pm 0.22 \mathrm{mmol} / 1$ after 6 months $(p<0.001)$. In the group of IPH optimization, the total level of cholesterol decreased after 1 month - at $29.2 \%$, after 6 months - at $30.1 \%$, and was $4.32 \pm 0.22$ $\mathrm{mmol} / \mathrm{l}$. After 6 months of rehabilitation, LDL levels were reduced at $35.1 \% \mathrm{mmol} / \mathrm{l}$ and their level was $2.80 \pm 0.19 \mathrm{mmol} / 1$.

The dynamics of the lipid profile in patients with STEMI is more significant, who were performed thrombolytic therapy and stenting, and data are represented in Table 4.

Dynamics of lipid phenotyping indices in patients with STEMI who were performed thrombolytic therapy and stenting

\begin{tabular}{|c|c|c|c|c|}
\hline \multirow{3}{*}{ Index, units of measurement } & \multicolumn{4}{|c|}{ therapy and stenting } \\
\hline & \multicolumn{4}{|c|}{ Observation period } \\
\hline & $\begin{array}{l}\text { At the beginning } \\
\text { of treatment }\end{array}$ & 1 week & 1 month & 6 months \\
\hline \multicolumn{5}{|c|}{ Traditional treatment $(n=19)$} \\
\hline $\begin{array}{l}\text { Total level of cholesterol, } \\
\mathrm{mmol} / \mathrm{l}\end{array}$ & $6.20 \pm 0.21$ & $6.05 \pm 0.22$ & $4.20 \pm 0.22 * * *$ & $4.16 \pm 0.21 * * *$ \\
\hline$\Delta$ & & -2.5 & -38.3 & -33.0 \\
\hline LDL cholesterol, mmol/l & $4.31 \pm 0.18$ & $4.31 \pm 0.17$ & $2.62 \pm 0.15 * * *$ & $2.58 \pm 0.19 * * *$ \\
\hline$\Delta$ & & & -39.3 & -40.2 \\
\hline HDL cholesterol, mmol/l & $1.12 \pm 0.03$ & $1.12 \pm 0.05$ & $1.16 \pm 0.03$ & $1.16 \pm 0.04$ \\
\hline$\Delta$ & & & +3.5 & +3.5 \\
\hline VLDL cholesterol, $\mathrm{mmol} / \mathrm{l}$ & $1.08 \pm 0.02$ & $1.06 \pm 0.08$ & $0.68 \pm 0.06^{* * *}$ & $0.67 \pm 0.07 * * *$ \\
\hline$\Delta$ & & -1.9 & -37.1 & -38.0 \\
\hline $\mathrm{TH}, \mathrm{mmol} / \mathrm{l}$ & $2.36 \pm 0.12$ & $2.32 \pm 0.13$ & $1.48 \pm 0.16^{* * *}$ & $1.47 \pm 0.16^{* * *}$ \\
\hline$\Delta$ & & -1.7 & -37.2 & -37.7 \\
\hline \multicolumn{5}{|c|}{ Traditional treatment with optimization of IPH $(n=19)$} \\
\hline $\begin{array}{l}\text { Total level of cholesterol, } \\
\mathrm{mmol} / \mathrm{l}\end{array}$ & $6.21 \pm 0.19$ & $6.02 \pm 0.19$ & $4.15 \pm 0.23 * * *$ & $4.08 \pm 0.22 * * *$ \\
\hline$\Delta$ & & -3.1 & -43.2 & -44.3 \\
\hline LDL cholesterol, $\mathrm{mmol} / \mathrm{l}$ & $4.30 \pm 0.17$ & $4.12 \pm 0.19$ & $2.51 \pm 0.11 * * *$ & $2.34 \pm 0.15^{* * *}$ \\
\hline$\Delta$ & & -4.2 & -41.7 & -45.6 \\
\hline HDL cholesterol, $\mathrm{mmol} / \mathrm{l}$ & $1.11 \pm 0.03$ & $1.12 \pm 0.03$ & $1.17 \pm 0.04$ & $1.20 \pm 0.05$ \\
\hline$\Delta$ & & +0.9 & +5.4 & +8.1 \\
\hline VLDL cholesterol, $\mathrm{mmol} / \mathrm{l}$ & $1.08 \pm 0.09$ & $1.05 \pm 0.08$ & $0.60 \pm 0.07 * * *$ & $0.58 \pm 0.06^{* * *}$ \\
\hline$\Delta$ & & -2.8 & -44.5 & -46.3 \\
\hline $\mathrm{TH}, \mathrm{mmol} / \mathrm{l}$ & $2.35 \pm 0.11$ & $2.28 \pm 0.12$ & $1.32 \pm 0.16^{* * *}$ & $1.28 \pm 0.17 * * *$ \\
\hline$\Delta$ & & -2.9 & -43.9 & -45.6 \\
\hline
\end{tabular}

1. Significance of difference of indices in comparison with values before treatment: $*_{-}<0.05 ; *_{\text {_ }}$

Notes: $<0.01 ; * * *_{-}<0.001$.

2. $\Delta$ - the percentage of increase $(+)$ /decrease $(-)$ compared to the values before the treatment.

At the beginning of treatment, the values of life quality were not found to be high according to all scales of the questionnaire; we have found the dependence of life quality on the chosen treatment tactics. Thus, after 6 months of treatment, higher quality of life was observed according to most scales in patients who were performed thrombolytic therapy with coronary artery stenting. In addition, the quality of life of the patient depends on age, gender and individual psychological characteristics (Fig.3).
At the same time, the patient's attitude to the disease is very important. Thus, the index of attitude to the disease according to the quality of life scale was low in all groups of patients at the beginning of treatment, but after 6 months of treatment with the use of traditional treatment with optimization of IPH a significant increase of this index was determined, at the beginning of treatment it was $-47 \pm 5 \%$, and after 6 months $87 \pm 4 \%$ $(\mathrm{p}<0.05)$ (Fig. 4). 


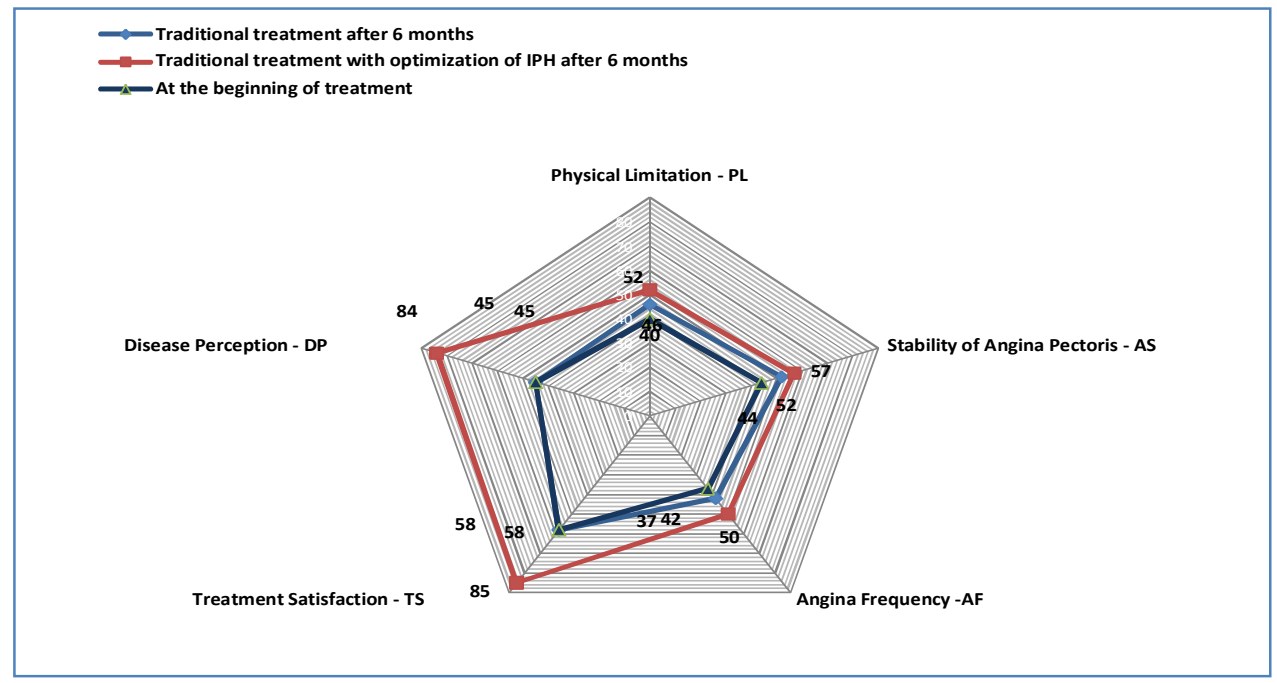

Fig. 3. Dynamics of life quality indices in patients with STEMI with conservative treatment

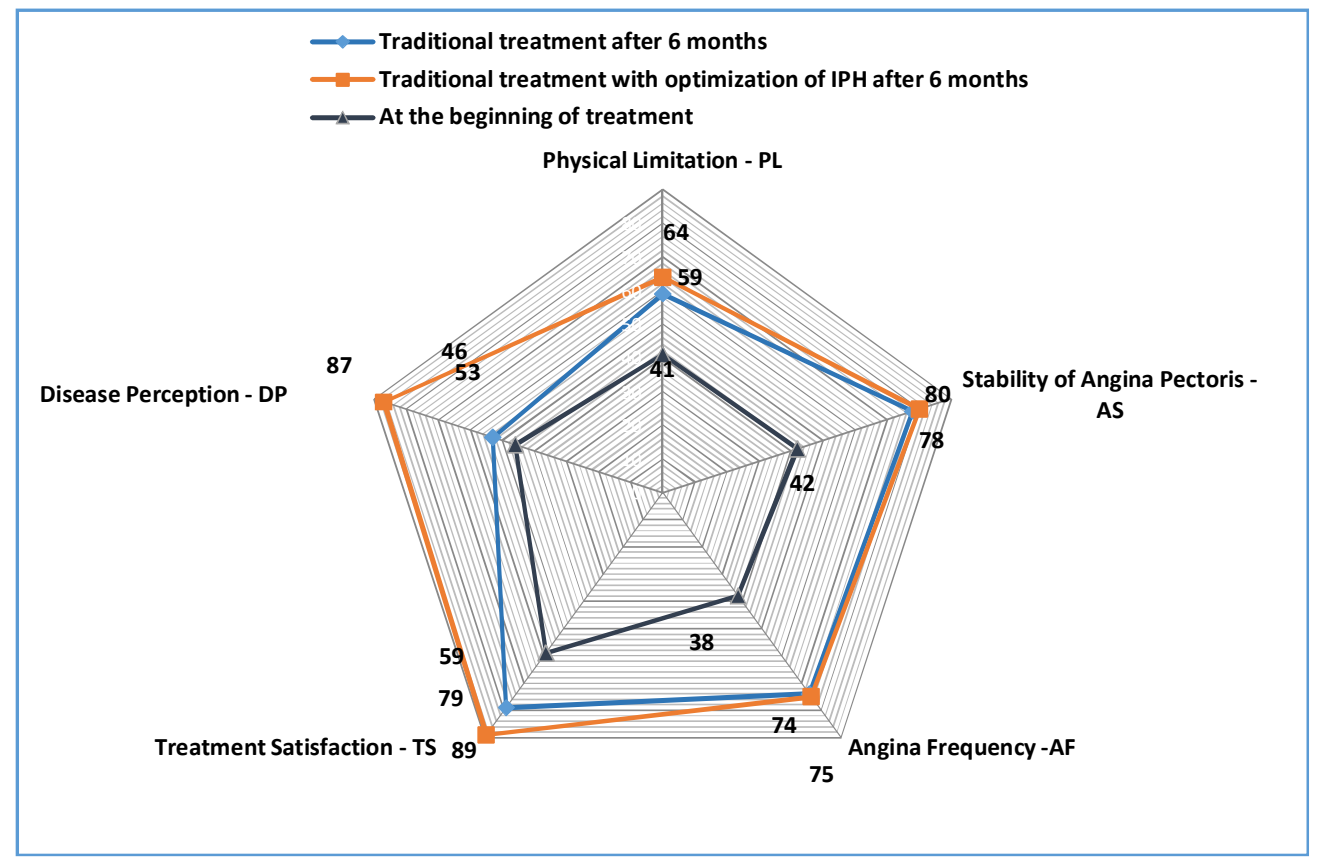

Fig. 4. Dynamics of life quality indices in patients with STEMI who were performed thrombolytic therapy and stenting

Traditional rehabilitation according to the "Program of Clinical-Psychological Rehabilitation by Optimization of the Internal Picture of Health" contributes to the optimization of IPH. The content of the optimization of each component of the internal picture of the cardiac patient's health is represented in Table 5.

Discussion of results. Traditional rehabilitation with IPH optimization creates the conditions for motivation to change behavioral risk factors, which encourages fuller use of secondary prevention tools.

Study of the peculiarities of the life quality of a cardiologic patient is an effective marker of evaluation of the quality and effectiveness of cardio-rehabilitation [12].

The application of the "Program of clinicalpsychological rehabilitation by optimization of the internal picture of health" in patients after acute coronary syndrome, meets the modern requirements of rehabilita- tion for a multidisciplinary approach with the provision of medical, physical and psychological components for complete correction of physical, psychological, emotional and social functioning of the patient.

Prospects for further research. The introduction of the application of the "Program of clinicalpsychological rehabilitation by optimization of the internal picture of health" in patients after cardiac surgery is of scientific-practical interest.

\section{Conclusions:}

1. Application of the "Program of clinical-psychological rehabilitation by optimization of the internal picture of health" in patients after acute coronary syndrome improves the functional recovery of patients, improving the clinical course of the rehabilitation period, indices of physical and psychological condition.

2. Optimization of rehabilitation measures after acute 
coronary syndrome contributes to the reduction of personal and reactive anxiety levels.

3. Implementation of effective rehabilitation measures leads to the correction of dyslipidemia with the decrease of levels of atherogenic lipoproteins

Table 5

Content optimization of components of the internal picture of health

\begin{tabular}{|c|c|}
\hline $\begin{array}{l}\text { Components of the } \\
\text { IPH, which the "Pro- } \\
\text { gram" optimizes }\end{array}$ & Content of correction \\
\hline$\underline{\text { Sensitive component }}$ & $\begin{array}{l}\text { - accepting and understanding the meaning of physical comfort or discomfort; } \\
\text { - the ability to obtain information about the disease through the symptom; } \\
\text {-empowerment of owning a body; } \\
\text { - formation of the actual and resource state of the person, understanding the dynamics of the } \\
\text { disease; } \\
\text { - through the feeling - the building of idea of the prospects for recovery and the possibilities of } \\
\text { body in the present; } \\
\text { - acceptance of the optimum of physical abilities which can be achieved after treatment and } \\
\text { rehabilitation; } \\
\text { - enjoyment of movement and progress in physiotherapy. }\end{array}$ \\
\hline$\frac{\text { Value-motivational }}{\text { component }}$ & $\begin{array}{l}\text { - increase of motivation for treatment and maintaining a healthy lifestyle; } \\
\text { - developing responsibility for one's health and awareness of one's own importance for making } \\
\text { vital decisions; } \\
\text { - improving understanding of one's system of values and values of health; } \\
\text { - expanding life prospects, finding new life goals; } \\
\text { - acceptance of the value of movement, support, recovery, increase of physical indices of an } \\
\text { organism }\end{array}$ \\
\hline Cognitive component & $\begin{array}{l}\text { - improving the range of knowledge about ways to support and improve health; } \\
\text { - deepening knowledge about the peculiarities of the disease; } \\
\text { - improvement of self-awareness, awareness and understanding of vital decisions that affect } \\
\text { health; } \\
\text { - expanding resources, developing the ability to identify successful health improvement } \\
\text { strategies; } \\
\text { - expanding the scope of knowledge about the content and effectiveness of physical activity in } \\
\text { physiotherapy }\end{array}$ \\
\hline$\frac{\text { Emotional }}{\underline{\text { component }}}$ & $\begin{array}{l}\text { - development of emotional self-awareness, improvement of the ability to analyze their mood; } \\
\text { - improving self-understanding and self-knowledge; } \\
\text { - promoting the acquisition of skills to overcome the devastating impact of emotions on health; } \\
\text { - reduction of anxiety level, improvement of state of health; } \\
\text { - forming successful strategies for developing confidence and optimizing emotional response to } \\
\text { one's health; } \\
\text { - development of awareness of positive emotions from the movement. }\end{array}$ \\
\hline $\begin{array}{l}\text { Behavioral } \\
\text { component }\end{array}$ & $\begin{array}{l}\text { the pursuit of a healthy lifestyle, the search for and awareness of health-promoting behaviour; } \\
\text { - developing an understanding of the consequences of one's behaviour for health, forming an } \\
\text { attitude about the importance of one's personality for health preservation; } \\
\text { - increase of vital activity and expansion of spheres of activity; } \\
\text { - awareness of strong qualities, disclosure of internal resources, activities according to new } \\
\text { strategies for solving difficult life situations; } \\
\text { - fulfillment of medical prescriptions and physiotherapy rehabilitation exercises both under the } \\
\text { supervision of a specialist and independently. }\end{array}$ \\
\hline
\end{tabular}

\section{References:}

1. Diachuk DD, Yashchenko YuB, Lysenko IIu. Poshyrenist khvorob systemy krovoobihu sered dorosloho naselennia, yakomu nadaietsia medychna dopomoha u DNU «NPTs PKM» DUS [Prevalence of circulatory system diseases among adults receiving medical care in DNU «NPTs PKM» DUS]. Visnyk problem biolohii i medytsyny.2015; 2(1):290-294. (Ukrainian).

2. Stadnik SM. Hostryy koronarnyy syndrom: trombolitychna terapiia abo koronarna interventsiia [Acute coronary syndrome: thrombolytic therapy or coronary intervention]. Meditsina neotlozhnykh sostoianiy. 2013; 7:115-123. (Ukrainian).
3. Dianati Maleki N, Van de Werf F, Goldstein P, Adgey JA, Lambert Y, Sulimov V, et al. Aborted myocardial infarction in ST-elevation myocardial infarction: insights from the strategic reperfusion early after myocardial infarction trial. Heart. 2014; 100(19):1543-1549.

4. Weintraub WS, Grau-Sepulveda MV, Weiss JM, O'Brien SM, Peterson ED, Kolm P, et al. Comparative effectiveness of revascularization strategies. $\mathrm{N}$ Engl $\mathrm{J}$ Med 2012; 366:1467-1476.

5. Ibanez B, James SK, Agewalls MJ, Bucciarelli-Ducci $\mathrm{C}$, Bueno $\mathrm{H}$ et al. ESC Guidelines for the management of acute myocardial infarction in patients presenting with ST-segment elevation The Task Force on the manage- 
ment of acute myocardial infarction in patients presenting with ST-segment elevation of the European Society of Cardiology (ESC). Eur Heart J. 2018; 39(2):119-177.

6. Smirnov VM, Reznikov TN. The basic principles and methods of psychological study of the internal picture of the disease. Methods of psychological diagnosis and correction in the clinic. 1983; P.38-62. (Russian).

7. Lisova OS. The internal picture of health. Psychology. Collection of scientific works. NPU named after MP Drahomanov. 2002; 15:69-77. (Ukrainian).

8. Lozhkin HV, Noskov VI, Tolkunova IV. Psykholohiia zdorov'ia liudyny [Psychology of human health]. Sevastopol: Veber. 2003. P.257. (Ukrainian).

9. Hasiuk MB. Nesterak RV. Vnutrishnia kartyna zdorovia khvorykh, shcho perenesly ishemichnu khvorobu sertsia ta infarkt miokarda: empirychne doslidzhennia [An internal picture of the health of patients with ischemic heart disease and myocardial infarction: an empirical study]. Naukovyi visnyk Khersonskoho derzhavnoho universytetu Seriya psykholohichni nauky. 2018; 2: 149-155. (Ukrainian).

10. Kuimov AD, Filippova OA, Petrova TV, Lozhkina NG. Jeffektivnost obuchenija $\mathrm{v}$ shkole dlja bol'nyh, prenesshih infarkt miokarda, na stacionarnom jetape reabilitacii [The effectiveness of training at school for patients who have suffered myocardial infarction at the stationary stage of rehabilitation]. Sibirskiy medicinskiy zhurnal . 2011; 26(1):98-101. (Russian).

11. Nesterak RV, Hasiuk MB, Vakaliuk IP. Avtorske pravo na tvir "Prohrama psykholohichnoi reabilitatsii kardiolohichnykh khvorykh shliakhom optymizatsii vnutrishnoi kartyny zdorov’ia” № 75681, zareiestrovane 29.12 2017. [Copyright on the piece "Program of psychological rehabilitation of cardiac patients by optimization of the internal picture of health" № 75681, registered 29.12 2017] (Ukrainian).

12. Nesterak RV, Hasiuk MB. Yakist zhyttia khvorykh z hostrym koronarnym syndromom bez elevatsii sehmenta [Quality of life for patients with acute coronary syndrome without segment elevation]. Molodyi vchenyi. 2018; 5(1):9-13. (Ukrainian).

\section{УДК 616.12-005.4-02:615.851-036.82 \\ ПРИМЕНЕНИЕ «ПРОГРАММЫ КЛИНИКО- ПИСХОЛОГИЧЕСОЙ РЕАБИЛИТАЦИИ ПУТЕМ ОПТИМИЗАЦИИ ВНУТРЕННЕЙ КАРТИНЫ ЗДОРОВЬЯ» У БОЛЬНЫХ ПОСЛЕ ОСТРОГО КОРОНАРНОГО СИНДРОМА}

\section{P.В. Нестерак}

Ивано-Франковский национальный медицинский университет, кафедра внутренней медииины №2 и медсестринства, г. Ивано-Франковск, Украина, ORCID ID: 0000-0002-4062-0939,

e-mail: roxolana.nesterak@gmail.com

Резюме. Цель. Проанализировать эффективность «Программы клинико-психологической реабилитации путем оптимизации внутренней картины здоровья» у больных после острого коронарного синдрома на этапе реабилитации.
Материалы. Обследовано 120 пациентов на острый коронарный синдром с елевацией сегмента ST. Анализировали клинико-анамнестические характеристики, лабораторные и инструментальные данные, проводили психометричекое анкетирование. Применяли традиционные реабилитационные мероприятия и реабилитацию по «Программе клиникопсихологической реабилитации кардиологических больных путем оптимизации внутренней картины здоровья».

Результаты исследования. Показатели уровней реактивной и личностной тревожности были высокими в начале наблюдения независимо от примененного метода лечения. Через месяц отмечалось уменьшение уровней реактивной тревожности, более значимыми изменения были в группе традиционного лечения с оптимизацией ВКЗ. Обнаружена позитивная динамика липидного профиля. Показатели качества жизни были низкими в начале лечения за всеми шкалами опросника SAQ. Через 6 месяцев лечения высшее качество жизни отмечали у пациентов, которым проведена тромболитическая терапия в сочетании с традиционным лечением с оптимизацией внутренней картины здоровья.

Выводы. Применение «Программы клиникопсихологической реабилитации путем оптимизации внутренней картины здоровья» у больных после острого коронарного синдрома улучшает состояние функционального возобновления пациентов, улучшая клиническое протекание реабилитационного периода, показатели физического и психологического состояния, способствует снижению уровней тревожности и коррекции проявлений дислипидемии.

Ключевые слова: острый коронарный синдром, тромболитическая терапия, реабилитация, программа, внутренняя картина здоровья.

\section{УДК 616.12-005.4-02:615.851-036.82 \\ ЗАСТОСУВАННЯ «ПРОГРАМИ КЛІНІ- КО-ПСИХОЛОГІЧНОЇ РЕАБІЛІТАЦІЇ ШЛЯ- ХОМ ОПТИМІЗАЦІЇ ВНУТРІШНЬОЇ КАРТИНИ ЗДОРОВ'Я» У ХВОРИХ ПІСЛЯ ГОСТРОГО КО- РОНАРНОГО СИНДРОМУ}

\author{
P.В. Нестерак \\ Івано-Франківський національний медичний \\ університет, кафедра внутрішньої медичини №2 \\ та медсестринства, м. Івано-Франківськ, Украӥна, \\ ORCID ID: 0000-0002-4062-0939, \\ e-mail: roxolana.nesterak@gmail.com
}

Резюме. Мета. Проаналізувати ефективність «Програми клініко-психологічної реабілітації шляхом оптимізації внутрішньої картини здоров'я» у хворих після гострого коронарного синдрому на етапі реабілітації.

Матеріали. Обстежено 120 пацієнтів на гострий коронарний синдром (ГКС) з елевацією сегмента ST. Аналізували клініко-анамнестичні характеристики хворих, лабораторні та інструментальні дані, проводили психометричну діагностику. Застосовува- 
ли традиційні реабілітаційні заходи та реабілітацію за «Програмою клініко-психологічної реабілітації кардіологічних хворих шляхом оптимізації внутрішньої картини здоров'я».

Результати дослідження. Показники рівнів реактивної та особистісної тривожності були високі на початку спостереження незалежно від застосованого методу лікування. Через місяць відмічалося зменшення рівнів реактивної тривожності, проте більш значимими ці зміни були у групі традиційного лікування 3 оптимізацією ВКЗ $(\mathrm{p}<0,05)$. Виявлено позитивну динаміку ліпідного профілю. Показники якості життя були низькими на початку лікування за усіма шкалами опитувальника SAQ. Через 6 місяців лікування вищу якість життя відмічали у пацієнтів, яким проведено тромболітичну терапію з поєднанням традиційного лікування 3 оптимізацією внутрішньої картини здоров'я.

Висновки. Застосування «Програми клінікопсихологічної реабілітації шляхом оптимізації внутрішньої картини здоров'я» у хворих після гострого коронарного синдрому покращує стан функціонального відновлення пацієнтів, клінічний перебіг реабілітаційного періоду, показники фізичного і психологічного стану, сприяє зниженню рівнів особистісної та реактивної тривожності та до корекції проявів дисліпідемії.

Ключові слова: гострий коронарний синдром, тромболітична терапія, реабілітація, програма, внутрішня картина здоров'я.

Стаття надійшла в редакцію 22.08.2019 р. 